\title{
EFFECT OF INORGANIC FERTILISERS ON GROWTH, YIELD AND ORGANOLEPTIC PROPERTIES OF TWO SWEET POTATO (Ipomoea BatatasL.)CULTIVARS
}

\author{
Nxumalo Kwazi, Mabuza Mzwandile* and Dlamini Bonginkhosi \\ Department of Crop Production, Faculty of Agriculture, University of Eswatini, P.O. Luyengo, Eswatini
}

https://doi.org/10.35410/IJAEB.2021.5624

\begin{abstract}
Eswatini farmers have been growing sweet potato for many years and it is an important indigenised root crop. The yield of sweet potato in Eswatini is below world average due to nonusage of inorganic fertilisers. Fertilisers are not used because they are perceived to compromise quality thus reducing consumer acceptability. A field experiment was conducted at the University of Eswatiniin the 2019/2020 cropping season to determine the yield and consumer acceptability of two popular sweet potato varieties. The experiment was laid out in a randomised complete block design in a $2 \times 3$ factorial arrangement, two sweetpotato varieties (Kenya white and Ligwalagwala); three blends of inorganic fertilisers namely 2:3:2 (22), P+K blend and Potassium chloride. The experiment was replicated three times. Results showed that there was no significant differences in tuber yieldamong the two varieties, Kenya white had $28378 \mathrm{~kg} / \mathrm{ha}$ and Ligwalagwala had $30897 \mathrm{~kg} / \mathrm{ha}$ on fresh mass basis. There was also no significant difference in tuber yieldacross the three inorganic fertilisers. However, the combination of Ligwalagwala variety with 2:3:2 (22) had the highest yield (32 $352 \mathrm{~kg} / \mathrm{ha})$ on fresh mass basis. Although not significant, consumers preferred Ligwalagwala that was fertilised with Potassium chloride. It is recommended that Ligwalagwala be grown using 2:3:2 (22).
\end{abstract}

Keywords: Sweetpotato, Kenya white, Ligwalagwala, inorganic fertiliser, and organoleptic properties.

\section{INTRODUCTION}

Eswatini farmers have grown sweet potato for many years and it is an important indigenised root crop, mostly for human consumption and sometimes the plants are used as livestock feed in the winter season (Ossom, 2010). The production of sweet potato in Eswatini has taken an upward trend since 2011 following technical assistance from the Republic of China-Taiwan. The Republic of China-Taiwan provided new high yielding varieties and helped in establishing nurseries across the country (Taiwan ICDF, 2018). Following decline in maize yields largely due to climate-change related late drought (National Maize Corporation, 2018), sweet potato is gaining popularity among Eswatini subsistence farmers. The shortage of chemical inputs, low organic matter in the soil and the limited irrigation facilities in Eswatini makes sweet potato a crop of choice for Swazi farmers (Ossom, 2010).In Eswatini sweetpotato is grown throughout the country though it favours the Highveld and Middleveld regions the most (Ossom et al., 2004). 
Many varieties have been identified for farmers' use in Eswatini and these include; Tainong 57, Kenya white and Tau-Yuan (Nxumalo, 2007). The most widely grown variety is the AVRDC1, popularly known as Ligwalagwala. These varieties are either white or purple skinned with white flesh with a high starch and dry matter content. It can produce good yield in a relatively short growing period of four months.

Sweet potato often yields fairlyineven on marginal soils but improving soil fertility also increasesits growth and yield performance (Onunkaet al., 2012). Potassium (K) nutrition is required in higher quantities compared to the other two main nutrients; nitrogen $(\mathrm{N})$ and phosphorus (P) (George et al., 2002;Belehu, 2003). Varietal response to applied $\mathrm{K}$ is often related to its yield potential and the number of large sized tubers it can produce. Yield is significantly depressed if $\mathrm{K}$ is deficient and tubers usually remove large quantities of $\mathrm{K}$ from the soil (Degras, 2003).Eliminating $P$ does not seem to affect the yield as the crop is well adapted to low levels of available $\mathrm{P}$ (Kareem, 2013).Delay in nitrogen application results in poor development of tubers. It is believed that the use of inorganic fertilisers can affect the organoleptic properties of sweet potato. Organoleptic properties are the aspects of food, water or other substances that create an individual experience via the senses; taste, sight, smell and touch (Yi et al., 2016). The overall preference of sweet potato is driven by flavour, followed by texture of the cultivar(Leksrisomponget al., 2012). It has always been a popular belief that inorganic fertilisers compromise the consumer acceptability of sweet potato (Ossom et al., 2011).

The objectives of this study were therefore, to determine the effect of inorganic fertilisers on growth, yield and organoleptic properties of two sweet potato varieties in the Wet Middleveld of Eswatini.

\section{MATERIALS AND METHODS}

\subsection{Experimental site}

A field trial was conducted at the Crop Production experimental Farm in the Faculty of Agriculture, University of Eswatini during the 2019/2020 cropping season. The site is located in the wet Middleveld of Eswatini, longitude $31.15^{\circ}$ East and latitude $26.55^{\circ}$ South and an altitude of $740 \mathrm{~m}$ above sea level. The area receives an average rainfall of $980 \mathrm{~mm}$ and an average temperature of $27 \mathrm{oC}$ in summer and $15 \mathrm{oC}$ in winter. The soil type is an Oxisol of the Malkerns soil series, which are dark loams and sand loams (Murdoch, 2000).

\subsection{Treatments and Experimental Design}

The experiment was laid out in a Randomised Complete Block Design (RCBD) in a factorial arrangement consisting of two sweet potato varieties and three inorganic fertilizer treatments in the 2019/2020 cropping season. The two sweet potato cultivars were Kenya white and Ligwalagwala. There were three inorganic fertiliser treatments; 2:3:2 (22) at $300 \mathrm{~kg} / \mathrm{ha}$, Phosphorus and Potassium blend at a ratio of 3:2 (22) at $300 \mathrm{Kg} / \mathrm{ha}$ and Potassium Chloride $(\mathrm{KCl})$ at $100 \mathrm{Kg} / \mathrm{ha}$. The experiment was replicated three times.

\subsection{Land preparation and planting}

The land was tilled and disked to a fine tilth. Ridges were made using a tractor at a depth of 30$45 \mathrm{~cm}$. Ridges were $90 \mathrm{~cm}$ apart and the space between sets was $30 \mathrm{~cm}$. Stem cuttings were from mature vinesand were $25 \mathrm{~cm}$ long. Cuttings were planted on top of the ridges vertically inclined on the 14th November 2019. To simulate the small-scale farmers' condition of minimal use of 
agro-chemicals, no chemicals were used to treat the cuttings before planting. The planting depth was $15 \mathrm{~cm}$ underground and the stems were buried with four to six nodes leaving two to three nodes above ground. Inorganic fertiliser was applied on sweet potato a week after planting using the dollop method.

\subsection{Data collected}

Data was collected at two weeks interval beginning from four weeks after planting until the twelfth week. Collected was on vine length per plant, number of branches per plant and number of leaves per plant. Yield and yield parameters were recorded at harvest. Data was collected on the net plot where five plants were randomly selected. Length of tubers per plant, diameter of tubers per plant, number of tubers per plant, mass of tubers per plant and tuber yield $(\mathrm{kg} / \mathrm{ha})$ on fresh mass basis were determined.

\subsection{Data analysis}

Data collected were subjected to analysis of variance by using GenStat statistical software 18th edition (Genstat, 2015). The mean separation was made using the Least Significance Difference (LSD) test at $5 \%$ level of significance.

\section{RESULTS}

\subsection{Vine length $(\mathrm{cm})$}

There was a significant difference in vine length among the two varieties. Ligwalagwala was significantly $(\mathrm{P}<0.05)$ longer at $6,8,10$ and 12 weeks after planting (Table 1$)$. There was an increase in vine lengths as the number of weeks increased and the vine lengths ranged from 19.2 $\mathrm{cm}$ in $\mathrm{P}+\mathrm{K}$ blend to $135.6 \mathrm{~cm}$ in Potassium chloride. There was no significant difference in vine length between the three inorganic fertilisers at $4,6,8,10$, and 12 weeks after planting. The interaction between Ligwalagwala with inorganic fertilisers showed the longest vine lengths compared to Kenya white with inorganic fertilisers over the twelve weeks period (Table 2).

Table 1. Main effects of variety and inorganic fertilisers on vine length $(\mathrm{cm})$ of sweetpotato collected over 12 weeks after planting (WAP).

\begin{tabular}{|llllll|}
\hline Treatment & 4 WAP & 6 WAP & 8 WAP & 10 WAP & 12 WAP \\
\hline Variety & & & & & \\
Kenya white & 17.0 & $24.0 \mathrm{~b}$ & $56.8 \mathrm{~b}$ & $80.3 \mathrm{~b}$ & $98.6 \mathrm{~b}$ \\
Ligwalagwala & 26.9 & $70.4 \mathrm{a}$ & $107.1 \mathrm{a}$ & $149.3 \mathrm{a}$ & $163.6 \mathrm{a}$ \\
LSD (0.05) & ns & 16.63 & 16.93 & 26.72 & 21.77 \\
\hline Fertiliser & & & & & \\
\hline
\end{tabular}


Vol. 06, No. 03; 2021

ISSN: $2456-8643$

\begin{tabular}{|c|c|c|c|c|c|}
\hline $\begin{array}{l}2: 3: 2 \quad(22)- \\
\text { control }\end{array}$ & 24.6 & 45.9 & 78.5 & 112.5 & 131.4 \\
\hline $\mathrm{P}+\mathrm{K}$ blend & 19.2 & 47.3 & 83.8 & 116.3 & 126.3 \\
\hline $\begin{array}{l}\text { Potassium } \\
\text { Chloride }\end{array}$ & 22.0 & 48.4 & 83.6 & 115.5 & 135.6 \\
\hline LSD (0.05) & ns & ns & ns & ns & ns \\
\hline CV\% & 47.6 & 33.6 & 19.7 & 22.2 & 15.8 \\
\hline
\end{tabular}

Means in column followed by the same letter or no letter are not significantly different to each other at $\mathrm{P}=0.05$ according to LSD test.

Table 2. Interaction effects of variety and inorganic fertilisers on vine length (cm) of sweetpotato collected over 12 weeks after planting (WAP).

\begin{tabular}{|llllll|}
\hline Treatment & 4 WAP & 6 WAP & 8 WAP & 10 WAP & 12 WAP \\
\hline Variety + Fertiliser & & & & & \\
Kenya white + 2:3:2 (22) & 19.6 & 24.4 & 54.8 & 78.3 & 95.3 \\
Kenya white + P+K blend & 15.4 & 23.8 & 65.4 & 85.5 & 106.6 \\
Kenya white + Potassium & 16.1 & 23.7 & 50.2 & 77.1 & 93.9 \\
Chloride & & & & & \\
Ligwalagwala + 2:3:2 (22) & 29.7 & 67.4 & 102.2 & 146.8 & 167.5 \\
Ligwalagwala + P+K blend & 23.0 & 70.8 & 102.2 & 147.1 & 146.1 \\
Ligwalagwala + Potassium & 27.8 & 73.0 & 117.0 & 153.9 & 177.2 \\
Chloride & & & & & $n$ \\
LSD (0.05) & $\mathrm{ns}$ & $\mathrm{ns}$ & $\mathrm{ns}$ & $\mathrm{ns}$ & $\mathrm{ns}$ \\
\hline CV\% & 47.6 & 33.6 & 19.7 & 22.2 & 15.8 \\
\hline
\end{tabular}

LSD $(0.05)=$ Least Significant Difference at $5 \%$ level, $\mathrm{CV}=$ Coefficient of variation, $\mathrm{ns}=$ nonsignificant at $\mathrm{P}=0.05$

Means in column followed by the same letter or no letter are not significantly different to each 
other at $\mathrm{P}=0.05$ according to $\mathrm{LSD}$ test.

\subsection{Number of branches per plant}

Profuse branching was seen in the Kenya white variety with 18.8 branches on the 12th week while Ligwalagwala had an average of 16.5 branches. Notable increases were seen in Kenya white branching between 10 and 12 weeks after planting. These differences in branching were significant $(\mathrm{P}<0.05)$ while they were not significant at earlier stages $(4,6$ and 8 weeks after planting). No significant differences were noted among the three fertiliser treatments in number of branches per plant (Table 3). However, the $\mathrm{P}+\mathrm{K}$ blend of fertiliser recorded the highest number of branches compared to the other two fertilisers as shown in the table below (Table 4). There was an increase in the number of branches with the increase of weeks but there was no significant difference between the interaction of the sweet potato varieties and inorganic fertilisers at 4, 6 and 8 weeks after planting. However, the combination of Kenya white with P+K blend recorded the highest number (20.8) of branches per plant.

Table 3. Main effects of variety and inorganic fertilisers on the number of branches per plant of sweetpotato collected over 12 weeks after planting (WAP).

\begin{tabular}{|c|c|c|c|c|c|}
\hline Treatment & 4 WAP & 6 WAP & 8 WAP & 10 WAP & 12 WAP \\
\hline \multicolumn{6}{|l|}{ Variety } \\
\hline Kenya white & 4.20 & 6.98 & 11.44 & $14.58 \mathrm{a}$ & $18.80 \mathrm{a}$ \\
\hline Ligwalagwala & 3.64 & 6.40 & 11.24 & $12.51 \mathrm{~b}$ & $16.56 \mathrm{~b}$ \\
\hline $\operatorname{LSD}(0.05)$ & ns & ns & ns & 1.25 & 1.21 \\
\hline \multicolumn{6}{|l|}{ Fertiliser } \\
\hline $\begin{array}{l}2: 3: 2 \quad \text { (22)- } \\
\text { control }\end{array}$ & 3.80 & 7.00 & 10.60 & 13.23 & 16.83 \\
\hline $\mathrm{P}+\mathrm{K}$ blend & 4.03 & 6.90 & 12.30 & 14.60 & 18.70 \\
\hline $\begin{array}{l}\text { Potassium } \\
\text { Chloride }\end{array}$ & 3.93 & 6.17 & 11.13 & 12.80 & 17.50 \\
\hline LSD (0.05) & ns & Ns & ns & ns & Ns \\
\hline CV\% & 24.7 & 29.8 & 20.3 & 8.8 & 6.5 \\
\hline
\end{tabular}

LSD $(0.05)=$ Least Significant Difference at $5 \%$ level, CV $=$ Coefficient of variation, $n s=$ nonsignificant at $\mathrm{P}=0.05$

Means in column followed by the same letter or no letter are not significantly different to each other at $\mathrm{P}=0.05$ according to LSD test. 
Table 4. Interaction effects of variety and inorganic fertilisers on the number of branches per plant of sweetpotato collected over 12 weeks after planting (WAP).

\begin{tabular}{|llllll|}
\hline Treatment & 4 WAP & 6 WAP & 8 WAP & 10 WAP & 12 WAP \\
\hline Variety + Fertiliser & & & & & \\
Kenya white + 2:3:2 (22) & 4.27 & 6.87 & 10.60 & $14.00 \mathrm{~b}$ & 17.73 \\
Kenya white + P+K blend & 4.00 & 7.20 & 12.00 & $16.80 \mathrm{a}$ & 20.80 \\
Kenya white + Potassium & 4.33 & 6.87 & 11.73 & $12.93 \mathrm{~b}$ & 17.87 \\
$\begin{array}{l}\text { Chloride } \\
\text { Ligwalagwala + 2:3:2 (22) }\end{array}$ & 3.33 & 7.13 & 10.60 & $12.47 \mathrm{~b}$ & 15.93 \\
Ligwalagwala + P+K blend & 4.07 & 6.60 & 12.60 & $12.40 \mathrm{~b}$ & 16.60 \\
Ligwalagwala + Potassium & 3.53 & 5.47 & 10.53 & $12.67 \mathrm{~b}$ & 17.13 \\
Chloride & & $\mathrm{ns}$ & & & \\
LSD $(\mathbf{0 . 0 5})$ & 24.7 & 29.8 & 20.3 & 8.8 & 6.5 \\
\hline CV\% & & & & & \\
\hline
\end{tabular}

LSD $(0.05)=$ Least Significant Difference at 5\% level, CV = Coefficient of variation, ns = nonsignificant at $\mathrm{P}=0.05$

Means in column followed by the same letter or no letter are not significantly different to each other at $\mathrm{P}=0.05$ according to LSD test.

\subsection{Number of leaves per plant}

The mean number of leaves ranged from 22.8 to 250.5 for all the interactions between the varieties and inorganic fertilisers. The trend in leaves per plant of sweet potato showed no significant differences between varieties and fertilisers at 4, 6, 8, 10, and 12 weeks after planting. At four weeks after planting the mean number of leaves per plant ranged from 22.8 in Ligwalagwala combined with $\mathrm{P}+\mathrm{K}$ blend to 29.3 in Kenya white combined with $\mathrm{P}+\mathrm{K}$ blend. During the last week of data collection week 12, the combination of Kenya white with $\mathrm{P}+\mathrm{K}$ blend recorded the highest number (250.5) of leaves per plant. Furthermore, the interaction between Kenya white with inorganic fertilisers showed the highest number of leaves compared to Ligwalagwala and inorganic fertilisers over the twelve weeks (Table 5). 
Table 5. Interaction effects of variety and inorganic fertilisers on the number of leaves per plant of sweetpotato collected over 12 weeks after planting (WAP).

\begin{tabular}{|llllll|}
\hline Treatment & 4 WAP & 6 WAP & 8 WAP & 10 WAP & 12 WAP \\
\hline Variety + Fertiliser & & & & & \\
Kenya white + 2:3:2 (22) & 27.7 & 57.8 & 118.0 & 119.1 & 214.6 \\
Kenya white + P+K blend & 29.3 & 65.0 & 140.3 & 222.8 & 250.5 \\
$\begin{array}{l}\text { Kenya white + Potassium } \\
\text { Chloride }\end{array}$ & 25.3 & 58.5 & 127.0 & 162.7 & 193.4 \\
Ligwalagwala + 2:3:2 (22) & 24.1 & 63.6 & 109.9 & 144.4 & 177.2 \\
Ligwalagwala + P+K blend & 22.8 & 53.6 & 123.4 & 145.2 & 169.5 \\
$\begin{array}{l}\text { Ligwalagwala + Potassium } \\
\text { Chloride }\end{array}$ & 23.7 & 47.3 & 105.2 & 137.6 & 171.3 \\
LSD (0.05) & $\mathrm{ns}$ & $\mathrm{ns}$ & $\mathrm{ns}$ & $\mathrm{ns}$ & $\mathrm{ns}$ \\
\hline CV\% & 21.5 & 24.9 & 23.9 & 22.3 & 19.7 \\
\hline
\end{tabular}

$\operatorname{LSD}(0.05)=$ Least Significant Difference at $5 \%$ level, $\mathrm{CV}=$ Coefficient of variation, $\mathrm{ns}=$ nonsignificant at $\mathrm{P}=0.05$

Means in column followed by the same letter or no letter are not significantly different to each other at $\mathrm{P}=0.05$ according to LSD test.

\subsection{Number of tubers per plant}

The number of tubers per plant ranged from 4.67 to 7.07. There was however, no significant difference $(\mathrm{P}<0.05)$ in number of tubers between the interaction of the sweet potato varieties and inorganic fertilisers at harvesting. The highest number of tubers per plant were recorded from the interaction between Ligwalagwala and potassium chloride (7.07) whilst the lowest was recorded from the Kenya white and potassium chloride (4.67). Furthermore the interaction between Ligwalagwala with inorganic fertilisers used revealed higher values than Kenya white with inorganic fertilisers (Figure 1). 
Means in bars followed by the same letters are not significantly different at 5\% level of significance.

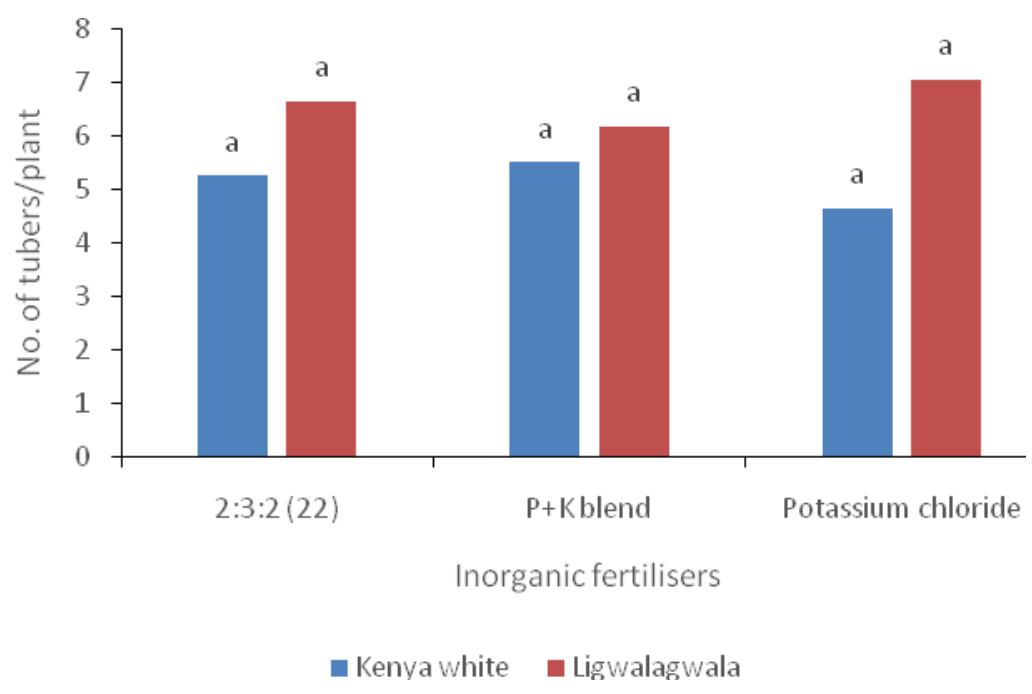

Figure 1. Showing the number of tubers per plant on the interaction between sweet potato varieties and inorganic fertilisers at harvesting.

\subsection{Mass of tubers per plant (g)}

The mass of tubers per plant ranged from $1089 \mathrm{~g}$ to $1356 \mathrm{~g}$. There was no significant difference in the mass of tubers between the interaction of the sweet potato varieties and inorganic fertilisers at harvesting. The largest mass of tubers per plant were recorded from the interaction between Kenya white with 2:3:2 (22), the control (1 356g) whilst the lowest was recorded from the Ligwalagwala with $\mathrm{P}+\mathrm{K}$ blend $(1089 \mathrm{~g})$ (Figure 2).

Mean values followed by the same alphabet were not significantly different at $\mathrm{P}<0.05$

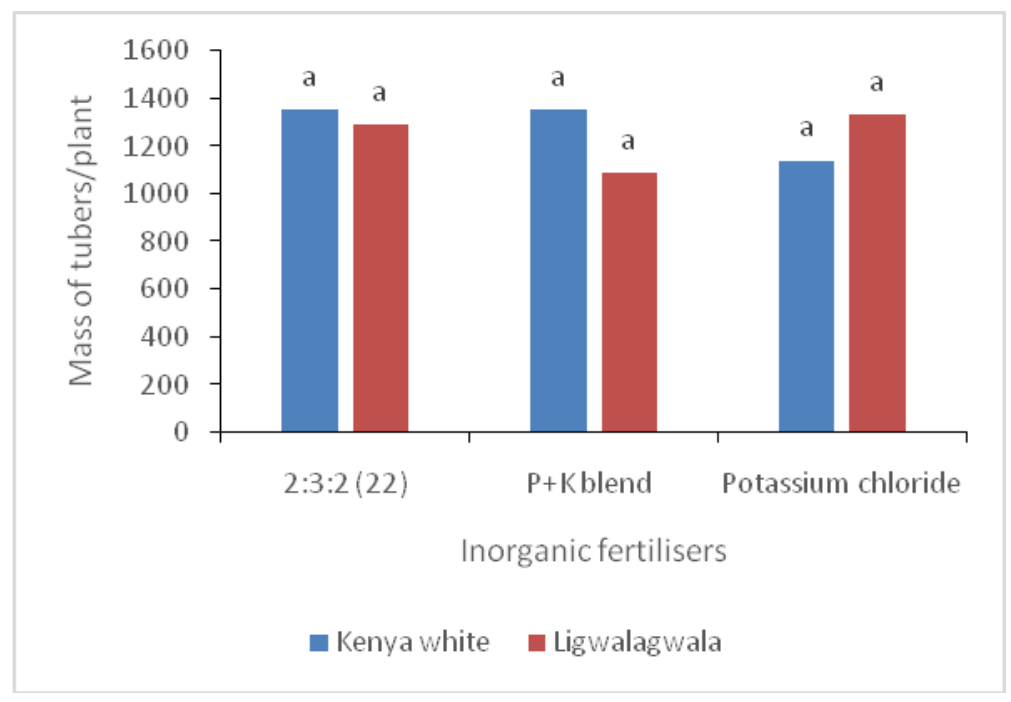


Figure 2. Showing the mass of tubers per plant on the interaction between sweet potato varieties and inorganic fertilisers at harvesting.

\subsection{Diameter of tubers $(\mathrm{cm})$}

The diameter of tubers ranged from 5.16 to $5.87 \mathrm{~cm}$. There was no significant difference in the diameter of tubers between the interaction of the sweet potato varieties and inorganic fertilisers at harvesting. The longest diameter of tubers was recorded from the interaction between Kenya white with Potassium chloride $(5.87 \mathrm{~cm})$ whilst the lowest was recorded from the Ligwalagwala with $\mathrm{P}+\mathrm{K}$ blend $(5.16 \mathrm{~cm})$ (Figure 3).

Mean values followed by the same alphabet were not significantly different at $\mathrm{P}<0.05$

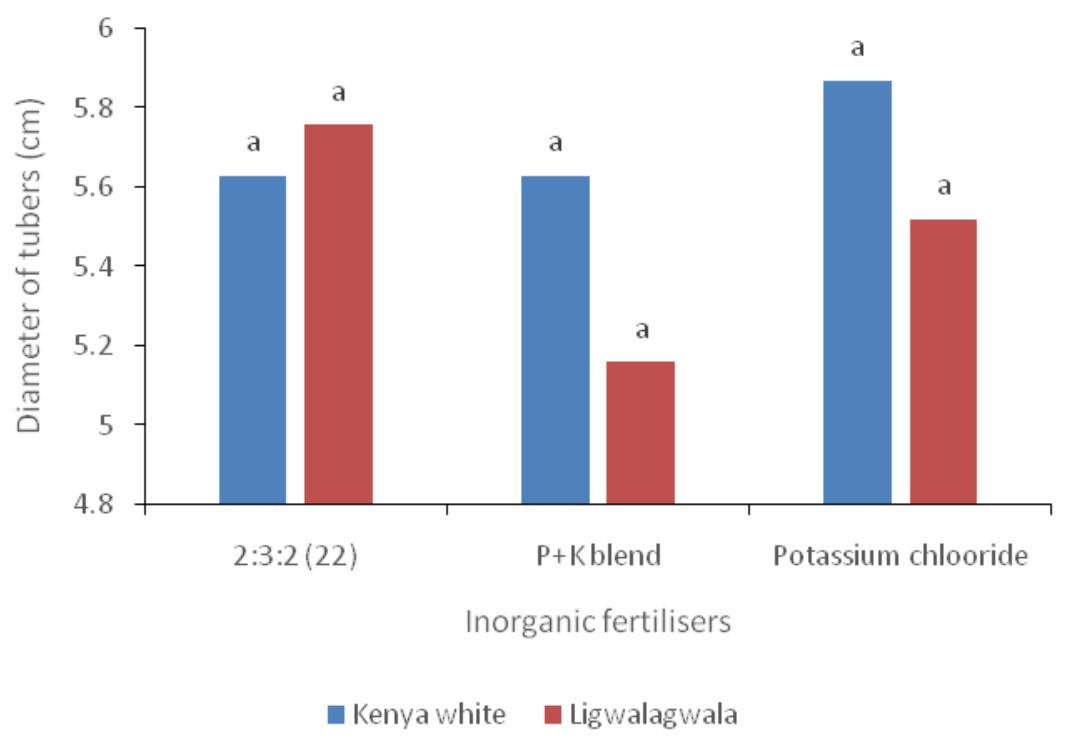

Figure 3. Showing the diameter of tubers on the interaction between sweet potato varieties and inorganic fertilisers at harvesting.

3.7 Tuber yield on fresh mass basis $(\mathrm{kg} / \mathrm{ha})$

The tuber yield ranged from 11102 to $14233 \mathrm{~kg} / \mathrm{ha}$. There was no significant difference in tuber yield between the interaction of the sweet potato varieties and inorganic fertilisers at harvesting. The highest tuber yield was recorded from the interaction between Ligwalagwala with 2:3:2 (22) (14 $233 \mathrm{~kg} / \mathrm{ha}$ ) whilst the lowest was recorded from the Kenya white with Potassium chloride (11 $102 \mathrm{~kg} / \mathrm{ha}$ ). Furthermore the interaction between Ligwalagwala with inorganic fertilisers used revealed higher values than Kenya white with inorganic fertilisers as shown below (Figure 4).

Mean values followed by the same alphabet were not significantly different at $\mathrm{P}<0.05$ 


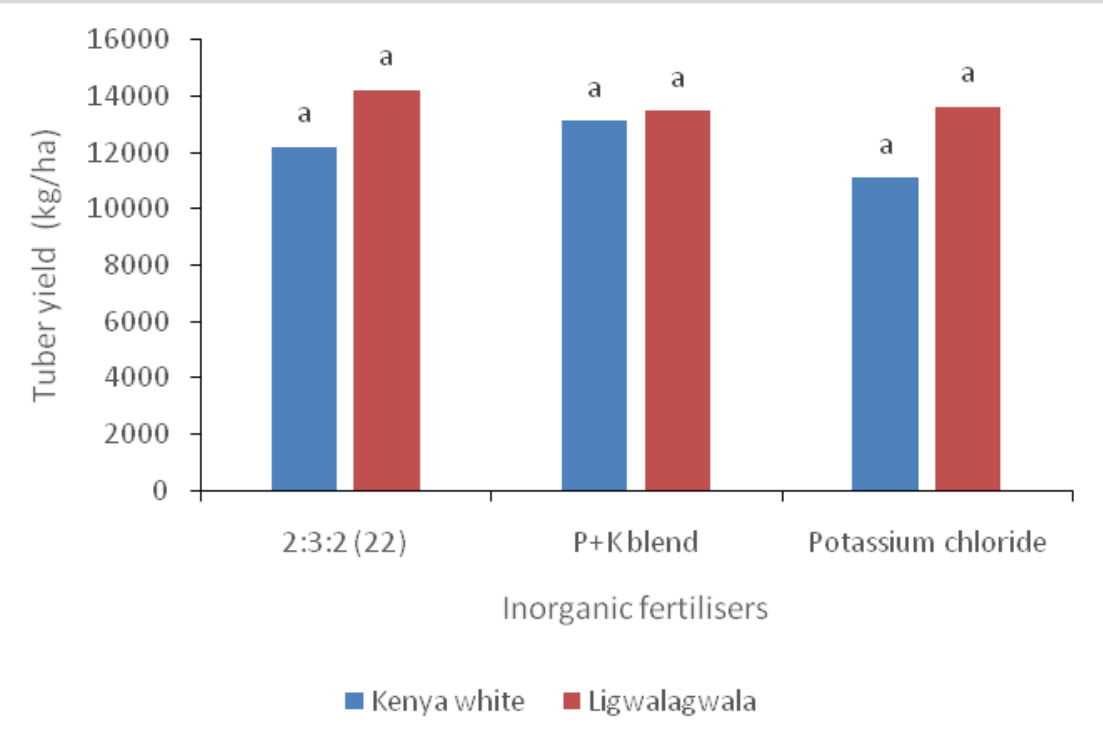

Figure 4. Tuber yield on the interaction between sweet potato varieties and inorganic fertilisers at harvesting.

\subsection{Organoleptic tests}

Ligwalagwala was significantly higher $(\mathrm{P}<0.05)$ in the overall acceptability of the people than the Kenya white variety. The highest overall acceptability was 5.7 from Ligwalagwala whilst the lowest was 4.59 from the Kenya white variety (Figure 5).

Mean values followed by the different alphabet were significantly different to each other at $\mathrm{P}<0.05$

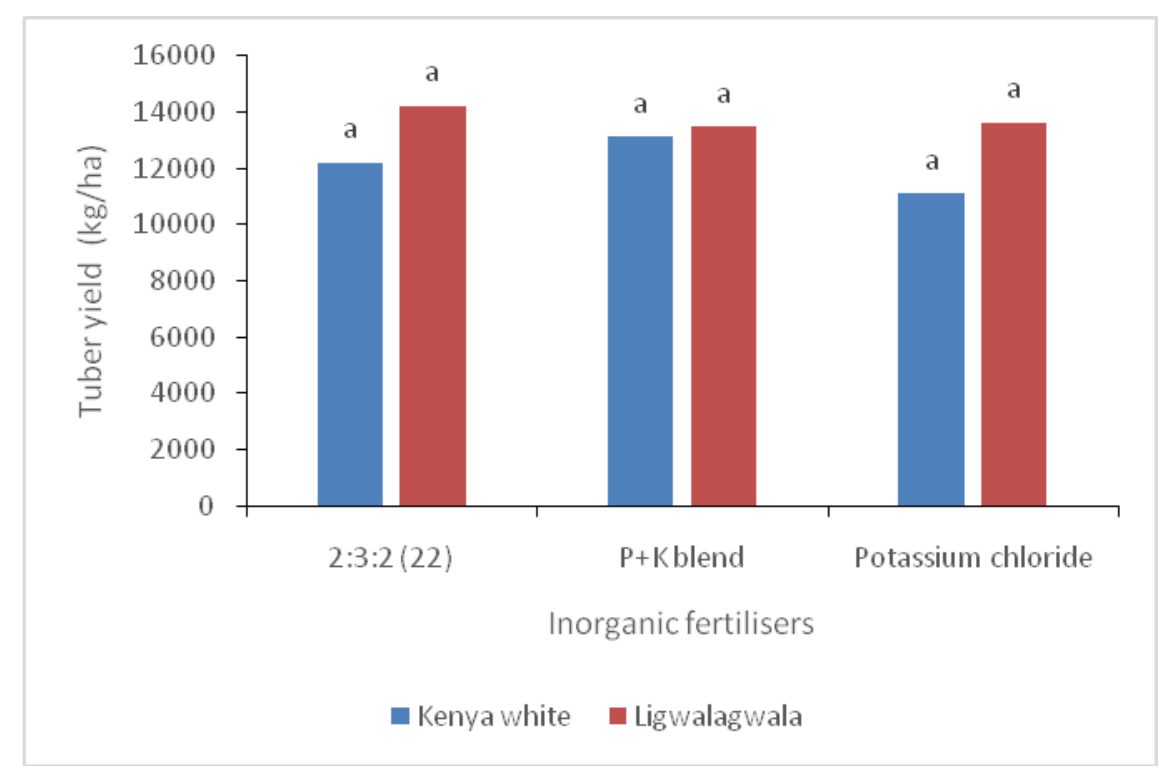

Figure 5. Overall acceptability ratings of the two sweetpotato varieties during organoleptic test 
The overall acceptability of sweet potato treated with inorganic fertilisers ranged 5.12 to 5.17. There was no significant difference in overall acceptability ratings among the three inorganic fertilisers. However the most preferred overall acceptability of sweet potato was the one treated with Potassium chloride (5.17), followed by the 2:3:2 (22) which recorded 5.15 and the least preferred was the one treated with Potassium chloride (5.12) (Figure 6).

Mean values followed by the same alphabet were not significantly different at $\mathrm{P}<0.05$

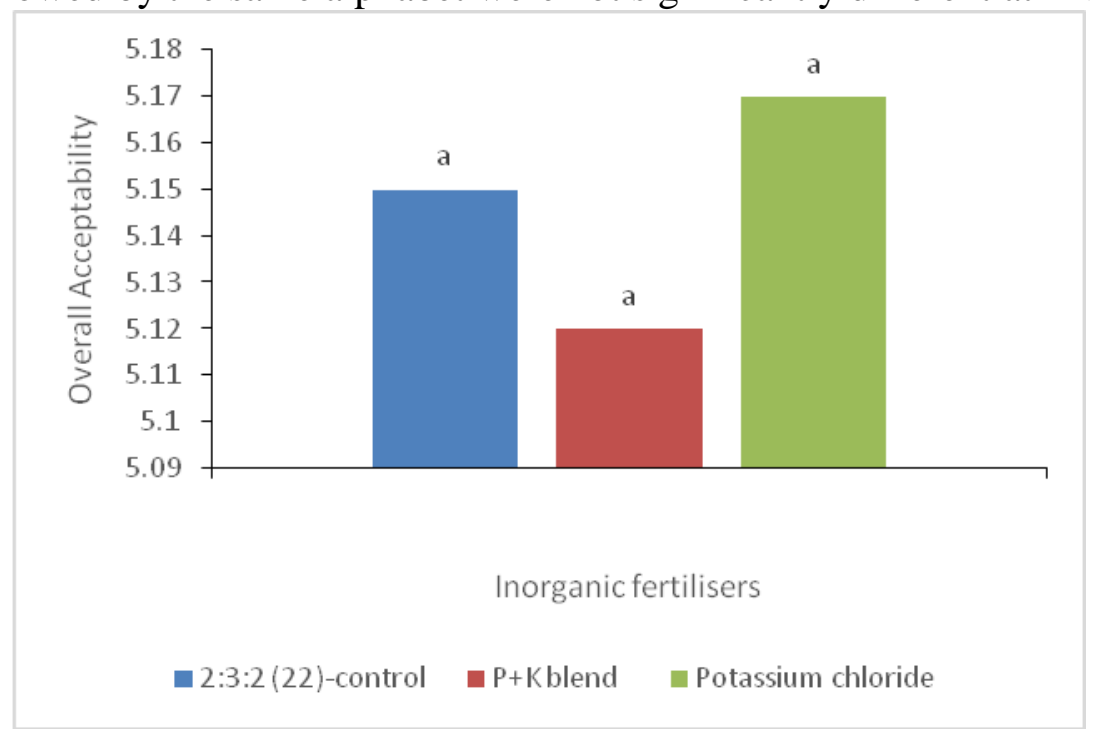

Figure 6. Overall acceptability ratings of the inorganic fertilisers during organoleptic test.

The overall acceptability ratings of a combination of sweet potato varieties and inorganic fertilisers ranged from 4.53 to 5.8. The results on organoleptic acceptability of sweetpotato proved that there was no significant difference between the interaction of sweet potato varieties and inorganic fertilisers. The highest acceptable sweetpotato in terms of taste and texture was the one from the interaction of Ligwalagwala with Potassium chloride (5.8) and the lowest was recorded from the interaction of Kenya white with $\mathrm{P}+\mathrm{K}$ blend and Kenya white with Potassium chloride (4.53) (Figure 7).

Mean values followed by the same alphabet were not significantly different at $\mathrm{P}<0.05$ 


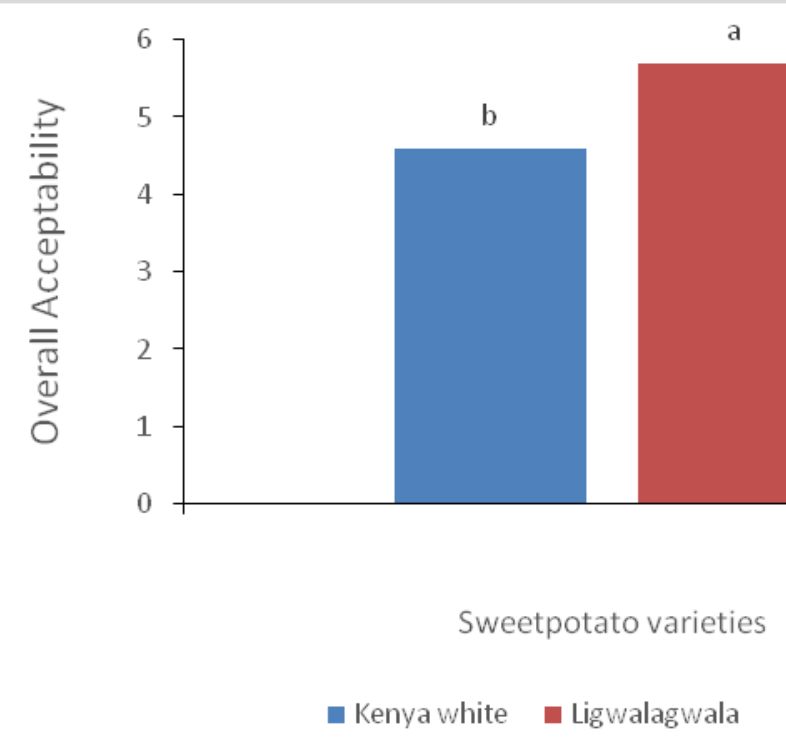

Figure 7. Overall acceptability ratings on the interaction between sweet potato varieties and inorganic fertilisers during organoleptic test.

\section{DISCUSSION}

This chapter covers discussion of results of the following parameters; vine length, number of branches per plant, the number of leaves per plant, length of tubers, tuber diameter, number of tubers per plant, mass of tubers per plant, tuber yield ( $\mathrm{kg} / \mathrm{ha})$, and organoleptic test.

\subsection{Vine length}

Vine length increased as the sweet potato continued growing. With the sweet potato varieties there was a significant difference $(\mathrm{P}<0.05)$ on the vine length with Ligwalagwala recording the longest vines compared to Kenya white at 6, 8, 10 and 12 weeks after planting. This could be due to the different adaptations of the three cultivars in the environment introduced as reported by (Hossain et al., 2000) that the growth of a sweet potato vine would depend on the conditions that the cultivar is introduced into and the genetic makeup of the cultivar itself. On the other hand was no significant difference on vine length within the three fertilisers at 4, 6, 8, 10 and 12 weeks after planting. However, although there was no significant difference the longest vines were in the Potassium Chloride at an average of $135.6 \mathrm{~cm}$. This may be because sweet potato have high demands for $\mathrm{K}$ because leaves, vines, stems and tubers usually remove substantial quantity of $\mathrm{K}$ from the soil as noted by Degras, (2003). The interaction between variety and fertiliser showed no significant difference within the 12 weeks. This indicate that the interaction between variety and fertiliser had no influence on the vine length of sweet potato. However, the interaction between Ligwalagwala and Potassium Chloride recorded the longest vines of $117.2 \mathrm{~cm}$ and the shortest was the interaction of Kenya white and Potassium Chloride. This shows that sweet potato's response to applied $\mathrm{K}$ is considerably influenced by the variety grown which is often related to its yield potential and the number of large sized tubers it can produce (Trehan, 2007).

\subsection{Number of branches}


Vol. 06, No. 03; 2021

ISSN: $2456-8643$

There was no significant difference on variety observed in the first three data collected but there was a significant difference $(\mathrm{P}<0.05)$ between Ligwalagwala and Kenya white thereafter at 10 and 12 weeks after planting. Kenya white recorded the highest number of branches from the start of data collection to the end (4.2-18.8). From these results it can be concluded that Kenya white is more branching compared to Ligwalagwala. Inorganic Fertiliser seemed to have no influence on the number of branches since there was no significant difference observed over the 12 weeks. Even though there was no significant difference observed, $\mathrm{P}+\mathrm{K}$ blend recorded the highest number of branches (18.7) compared to the other two fertilisers. For this reason, sweet potato requires equal ratios of potassium and phosphorus for branching. The interaction between variety and fertiliser had no significant difference at 4, 6, 8 and 12 weeks after planting. Nevertheless, there was a significant difference $(\mathrm{P}<0.05)$ at 10 weeks after planting. Following this was the fact that the interaction between variety and fertiliser had a major factor on the branching of sweet potato. Kenya white and $\mathrm{P}+\mathrm{K}$ blend resulted in the highest number of branches (20.8). Zalalenet al. (2009) reported that the number of branches depend more on the intrinsic potential of the cultivar than addition of fertilizer. Thus branch number may be influenced by other factors such as genetic potential of the cultivar, the number of available sprouts at planting, sprout damage before planting and after planting.

\subsection{Number of leaves}

The trend in leaves per plant of sweet potato shows that there was no significant difference on variety at four, six and eight weeks after planting. Number of leaves grow as the sweet potato continues growing. However, there was a significant difference in the number of leaves between Kenya white and Ligwalagwala at 10 and 12 weeks after planting. Kenya white had the highest number of leaves (219.5) over the 12 weeks. As a result of Kenya white having the highest number of branches no doubt it will have the highest number of leaves also.

There was no significant difference in the number of leaves in three fertilisers. This indicated that fertiliser incorporation is not a major factor that affects number of leaves per plant. However, although there was no significant difference the highest number of leaves were in the $\mathrm{P}+\mathrm{K}$ blend fertiliser at an average of 210 and the smallest were in potassium chloride at 182.4.

The interaction of variety and fertiliser had no effect on the number of leaves since there was no significant difference observed over the 12 weeks of data collection. However, the interaction between Kenya white and $\mathrm{P}+\mathrm{K}$ blend had the highest number of leaves (250.5) compared to the other treatments.

\subsection{Number of tubers per plant}

Ligwalagwala was significantly higher $(\mathrm{P}<0.05)$ in the number of tubers per plant than the Kenya white variety. This could be due to the better adaptation of Ligwalagwala compared to Kenya white. On the contrary there was no significant difference $(\mathrm{P}<0.05)$ in the number of tubers among the three inorganic fertiliser however, sweet potato treated with 2:3:2 (22) the control recorded the highest tuber number per plant. Greater tuber number could be a result of adequate supply of the nutrients; Nitrogen, Phosphorus and Potassium (Masibuka, 2016) in the control. Although there was also no significant difference $(\mathrm{P}<0.05)$ in the tuber number per plant from the interaction between sweet potato varieties and inorganic fertilisers, Ligwalagwala with Potassium chloride recorded the highest tuber number per plant. These results agrees well with 
Vol. 06, No. 03; 2021

ISSN: $2456-8643$

those of (Degras, 2003) who mentioned that Potassium also affects the number, size, quality and the unit weight of tuberous roots produced.

\subsection{Mass of tubers per plant}

Kenya white recorded the largest mass of tubers per plant even though it recorded the minimum number of tubers per plant. This could be the fact that the variety had long and wide tubers compared to Ligwalagwala which resulted in larger mass. There was also no significant difference $(\mathrm{P}<0.05)$ in the mass of tubers per plant among the three inorganic fertilisers, but the largest mass was found in the control. This could resulted from the adequate supply of nitrogen, potassium and phosphorus as mentioned above. Also the interaction of these two resulted to the lager mass of tubers per plant.

\subsection{Length of tubers $(\mathrm{cm})$}

There was no significant difference $(\mathrm{P}<0.05)$ in length of tubers between the two sweet potato varieties but the longest tubers were found in the Kenya white variety. These results correlated with (Hossain, et al., 2000) who reported that high number of leaves present in sweet potato plant causes thick tubers due to the high photosynthesis rate. Since the Kenya white variety had more leaves it was able to produce more sugars for its tubers hence the growth of the tubers was high. Similarly, there was no significant difference $(\mathrm{P}<0.05)$ among the three inorganic fertilisers but the longest tuber length was recorded in sweet potato treated 2:3:2 (22), the control. This shows that fertiliser had no influence on the length of tubers. There was also no significant difference observed from the interaction between sweet potato varieties and inorganic fertilisers, however the interaction between Kenya white and the control recorded the longest tubers.

\subsection{Diameter of tubers $(\mathrm{cm})$}

Kenya white was significantly higher $(\mathrm{P}<0.05)$ in tuber diameter $(\mathrm{cm})$ than the Ligwalagwala variety. These results correlated with (Hossain, et al., 2000) who reported that high number of leaves present in sweet potato plant causes thick tubers due to the high photosynthesis rate. Since the Kenya white variety had more leaves it was able to produce more sugars for its tubers hence the growth of the tubers was high. However, there was no significant difference $(\mathrm{P}<0.05)$ in tuber among the three inorganic fertilisers but the highest tuber diameter was recorded on sweet potato treated with Potassium chloride. These results supports that potassium is the most important nutrient in the production of sweet potato as its application increases yield by the formation of larger sized tubers as reported by Degras (2003). There was also no significant difference in the diameter of tubers between the interaction of sweet potato varieties and inorganic fertilisers at harvesting. The longest diameter of tubers was recorded from the interaction between Kenya white with Potassium chloride.

\subsection{Tuber yield (kg/ha)}

In sweet potato production, varieties play a significant role in yield improvement (Nednchezhiyanet al., 2012). There was no significant difference $(\mathrm{P}<0.05)$ in tuber yield between the two sweet potato varieties but the Ligwalagwala variety recorded the highest tuber yield. The differences between the sweet potato tuber yields could be attributed to different stages of storage roots development at harvesting. Storage root initiation is not spontaneous and can take 
Vol. 06, No. 03; 2021

ISSN: $2456-8643$

place over days due to the variability in cutting establishment, which in turn contributes to yield variability. Induction of fibrous roots into formation of storage root varies from plant to plant such that some plants yield with a high number of 4 to 6 storage roots per plant and sometimes less (Villordonet al., 2009). Again there was no significant difference $(\mathrm{P}<0.05)$ in tuber yield among the inorganic fertiliser whereas the control [2:3:2 (22)] recorded the highest yield. This was due to the facts reported by Masibuka (2016) who stated that greater marketable tuber yield could be a result of adequate supply of nutrients particularly Nitrogen, Phosphorus and Potassium. There was also no significant difference $(\mathrm{P}<0.05)$ in tuber yield between the interaction of varieties and inorganic fertilisers. Although, the interaction between Ligwalagwala and the control recorded the highest tuber yield. This was supported by Laxminarayana (2011) who reported that application of graded doses of NPK significantly increased the dry matter content.

\subsection{Organoleptic tests}

There is little published information on sensory attributes and quality indices of inorganically grown sweetpotato (IpomeabatatasL.) even though there is a growing demand for this product. The study was conducted to identify the organoleptic acceptability of sweetpotato grown under an inorganic management production system. The overall preference of sweet potato is driven by flavour followed by texture of the cultivar (Leksrisomponget al., 2012). The results shows that the overall accepted variety was the Ligwalagwala over the Kenya white since there was a significant difference $(\mathrm{P}<0.05)$ between the two. Sweetpotato grown in potassium chloride fertiliser was the preferred from the overall ratings but there was no significant difference $(\mathrm{P}<0.05)$ between fertilisers. The interaction between Ligwalagwala with Potassium chloride was highly accepted by panellists in terms of taste and texture. The least acceptable sweet potato was recorded from the interaction between Kenya with Potassium chloride. However, there was no significant $(\mathrm{P}<0.05)$ difference in all treatments. Leksrisomponget al., (2012) mentioned that the overall preference of sweet potato is driven by flavour followed by texture of the cultivar.

\section{CONCLUSION}

It is concluded that Kenya white variety fertilised using $\mathrm{P}+\mathrm{K}$ had the highest yield of 14233 $\mathrm{kg} / \mathrm{ha}$ on fresh mass basis. Ligwalagwala that received compound fertiliser had the highest number of tubers per plant.Organoleptic tests showed that Ligwalagwala fertilised with potassium chloride was the most preferred by panellists. However, to reach at a conclusive recommendation, the experiment has to be repeated over more years with inclusion of more treatments and economic evaluation.

\section{REFERENCES}

Belehu, T. (2003). Agronomical and physiological factors affecting growth, development and yield of sweet potato in Ethiopia. Unpublished thesis, University of Pretoria, South Africa.

Degras, L. (2003). Sweet potato. The Tropical Agriculturalist. Macmillian Publishers Ltd., Malaysia.

Edge, O. T. and Ossom, E. T. (2016). Crop Science Handbook Second Edition. Blue moon publishers, Manzini, Swaziland.

GENSTAT. Genstat for Windows 18th Edition. VSN International, Hemel Hempstead, UK; 2015. 
Vol. 06, No. 03; 2021

ISSN: $2456-8643$

George, M. S., Lu, G. Q., and Zhou, W. J. (2002). Genotypic variations for potassium uptake and utilization efficiency in sweet potato (IpomeabatatasL.). Field Crops Research 77: 7-15.

Hossain, M. D., Rabbani, M. G., and Mollah, M. L. R. (2000). Genetic variability, correlation and path analysis of yield contributing characters in sweetpotato (Ipomoea batatas L). Pakistan Journal of Scientific and Industrial Research, 43(5):314-318.

Leksrisompong, P. P., Whitson M. E., Truong V. D., and Drake M. A. (2012). Sensory Attributes and Consumer Acceptance of Sweet Potato Cultivars with Varying Flesh colours. Journal of Sensory Studies 27: 56 - 69.

Murdoch, G. (2000). Soils and land capability in Swaziland. Swaziland Ministry of Agriculture. Mbabane, Swaziland.

Nednchezhiyan, M., Byju, G. and Jata, S. K. (2012). Sweet potato Agronomy. Fruit, Vegetable and Cereal Science and Biotechnology6: 1-10.

Nxumalo, M. (2007). Sweetpotato production guide. Ministry of Agriculture and Cooperatives. Mbabane, Swaziland.

Onunka, N. A., Chukwu, L. I., Mbanasor, E. O., and Ebeniro, C. N. (2012). Effect of organic and inorganic manures and time of application on soil properties and yield of sweet potato in a tropical ultisol. Journal of Agriculture and Social Research 12 (1): 182-193.

Ossom, E. M. (2010). Influence of sweet potato/maize association on ecological properties and crop yields in Swaziland. International Journal of Agriculture and Biology 12: 481-488.

Ossom, E. M., Mavuso, N. S., Seyoum, T., and Nkambule, T. P. (2011). Influence of Sunnhemp (CrotolariajunceaL) on Agronomic and Sensory Characteristics of Sweet Potato (Ipomeabatatas(L.) Lam) in Swaziland. Libyan Agriculture Research Center Journal Inernational. 2(2): $39-50$.

Ossom, E.M., Nxumalo, M, H. and Badejo, F. M. (2004). Evaluating Different Traditional Storage Methods on the Shelf Life of Sweet Potato Tubers in Swaziland. Final report submitted to UNESWA ResearchBoard, University of Swaziland, Kwaluseni, Eswatini, September, 2004.

Taiwan-ICDF. (2018). Sweet Potato Production and Marketing Project (Swaziland). 12-15F, No. 9, Lane 62, Tien Mou West Rd., Taipei 111047, Taiwan.

Trehan, S. P. (2007). Efficiency of potassium utilization from soil as influenced by different potato cultivars in the absence and presence of green manure (Sesbania aculeate). Advance in Horticultural Sciences 21 (3): 156-164.

Zelalem, A., Tekalign, T. N. and Gussie, D. (2009).The response of potato (SolanumtuberosumL.) to different rates of nitrogen and phosphorus fertilization on vertisols at DebreBerhan, in the central highlands of Ethiopia. Africa Journal Plant Science 3(2): 16 - 24.

Masibuka K.C (2016), Response of sweetpotato (ImpomoeabatatasLam.) to organic and inorganic fertilizers in loamy sand soil at Tububi, Tabora, Tanzania.

Villordon, D. R., La Bonte, D. R., Firon, N., Kfir, K., Pressman, E., and Schwartz, A. (2009). Characterization of Adventitious Root Development in Sweetpotato. Hortictural Science 44:651655 